\title{
Effect of Anions during a Solid-state Reaction Preparation of Ammonium Aluminum Carbonate Hydroxide
}

\author{
Xiaofu $\mathrm{Hu}$ \\ State Key Laboratory of Heavy Oil Processing, Key \\ Laboratory of Catalysis CNPC \\ China University of Petroleum \\ Qingdao, Shandong, China, 266555 \\ hjj19850922@126.com \\ Yunqi Liu \\ State Key Laboratory of Heavy Oil Processing, Key \\ Laboratory of Catalysis CNPC \\ China University of Petroleum \\ Qingdao, Shandong, China, 266555
}

\author{
Zhe Tang \\ State Key Laboratory of Heavy Oil Processing, Key \\ Laboratory of Catalysis CNPC \\ China University of Petroleum \\ Qingdao, Shandong, China, 266555 \\ Chenguang Liu \\ State Key Laboratory of Heavy Oil Processing, Key \\ Laboratory of Catalysis CNPC \\ China University of Petroleum \\ Qingdao, Shandong, China, 266555
}

\begin{abstract}
Ammonium aluminum carbonate hydroxide (AACH) can be obtained from different anions of aluminum sources by a solid-state reaction. Anions play a crucial role on the properties of AACH. It is observed that best-crystallized AACH can be obtained from $\mathrm{Al}_{2}\left(\mathrm{SO}_{4}\right)_{3}$. Depending on the nature of anion present during synthesis, $\mathrm{AACH}$ obtained either from $\mathrm{Al}_{2}\left(\mathrm{SO}_{4}\right)_{3}$ or $\mathrm{AlCl}_{3}$ has the similar phase transformations calcined at different temperatures, which is different from AACH obtained from $\mathrm{Al}\left(\mathrm{NO}_{3}\right)_{3}$. The specific surface area $\left(\mathrm{S}_{\mathrm{BET}}\right)$ of alumina prepared by $\mathrm{Al}_{2}\left(\mathrm{SO}_{4}\right)_{3}$, which is obtained from the calcination of AACH at $500^{\circ} \mathrm{C}$, is still in $610.6 \mathrm{~m} 2 / \mathrm{g}$.
\end{abstract}

Keywords-solid-state reaction; ammonium aluminum carbonate hydroxide; aluminum source

\section{INTRODUCTION}

Alumina is the most commonly used as adsorbents, catalysts, and catalyst supports ${ }^{[1.2]}$, due to its good thermal stability, high specific surface area and modulated acid-base properties according to its synthesis conditions ${ }^{[3.4]}$. Usually, alumina is obtained by dehydroxylation of boehmite through precipitation from aluminum chloride or nitrate ${ }^{[5]}$, hydrolysis of aluminum alkoxides ${ }^{[6.7]}$, or thermal decomposition of $\mathrm{AACH}$ reported on our preious articles ${ }^{[8.9]}$. So far, the role of the anionic part of the aluminum salt on capability to form insoluble precursor powders for the preparation of alumina has been studied ${ }^{[10]}$. But a comparison of the influence of the anionic part of the aluminum source on capability of AACH precursor, including the crystallinity, morphology and thermal decomposition behavior, prepared by a solid-state reaction has

Financial support from the National Basic Research Program of China (No.2010CB226905) and the National Natural Science Foundation, China (No.21176258, U1162203) and Specialized Research Fund for the Doctoral Program of Higher Education, (No.20110133110002) and the Fundamental Research Funds for the Central Universities, (No.27R1104065A) are gratefully acknowledged. not been reported.

The aim of this work is to study the effect of anions on AACH precursors obtained from a solid-state reaction. Meanwhile, the effect of anions on textural properties and morphology of alumina obtained by calcining AACH is also investigated.

\section{EXPERIMENTAL}

\section{A. Preparation of Samples}

All chemicals are analytical-grade regents without further purification. In a typical experiment, an amount of PEG-400 was added very slowly to $\mathrm{NH}_{4} \mathrm{HCO}_{3}$. The agate mortar was used for grinding the mixture of PEG-400 and $\mathrm{NH}_{4} \mathrm{HCO}_{3}$.

After the mixture was ground sufficiently, the powder of aluminum salt (using the same $\mathrm{Al}^{3+}$ molar ratio) was added. The final mixture was ground at room temperature for $20 \mathrm{~min}$, transferred to a Teflon-lined stainless-steel autoclave and placed in an oven at $80^{\circ} \mathrm{C}$. After $7 \mathrm{~h}$, the solid was filtered off, washed with deionized water and anhydrous ethanol to move the impurities, and dried at $120^{\circ} \mathrm{C}$ in a vacuum oven for $2 \mathrm{~h}$. The PEG-400 was removed by calcination in air at $500^{\circ} \mathrm{C}$ for $4 \mathrm{~h}$ with heating rate of $2^{\circ} \mathrm{C} / \mathrm{min}$. The effect of aluminum salts was examined as detailed in Table 1.

TABLE I. THE EFFECT OF ANIONS ON PREPARING DIFFERENT ALUMINA NANOSTRUCTURE SAMPLES

\begin{tabular}{|c|c|c|c|}
\hline \multirow{2}{*}{ Sample } & \multicolumn{3}{|c|}{ Materials } \\
\cline { 2 - 4 } & Aluminum salts (g) & $\begin{array}{c}\mathbf{N H}_{4} \text { HC } \\
\boldsymbol{O}_{3}(\boldsymbol{g})\end{array}$ & $\begin{array}{c}\text { PEG-400 } \\
(\boldsymbol{m L})\end{array}$ \\
\hline \multirow{2}{*}{$\mathrm{Al}-\mathrm{S}$} & $\mathrm{Al}_{2}\left(\mathrm{SO}_{4}\right)_{3} \cdot 18 \mathrm{H}_{2} \mathrm{O}$, & 15.80 & 0.16 \\
\hline
\end{tabular}




\begin{tabular}{|c|c|c|c|}
\hline \multirow{2}{*}{ Sample } & \multicolumn{3}{|c|}{ Materials } \\
\cline { 2 - 4 } & Aluminum salts (g) & $\begin{array}{c}\mathbf{N H}_{4} \text { HC } \\
\boldsymbol{O}_{3}(\boldsymbol{g})\end{array}$ & $\begin{array}{c}\text { PEG-400 } \\
(\boldsymbol{m L})\end{array}$ \\
\hline $\mathrm{Al}-\mathrm{N}$ & $\mathrm{Al}\left(\mathrm{NO}_{3}\right)_{3} \cdot 9 \mathrm{H}_{2} \mathrm{O}$, & 15.80 & 0.16 \\
\hline $\mathrm{Al}-\mathrm{Cl}$ & $\mathrm{AlCl}_{3} \cdot 6 \mathrm{H}_{2} \mathrm{O}, 12.07$ & 15.80 & 0.16 \\
\hline
\end{tabular}

\section{B. Characterization}

X-ray powder diffraction (XRD) analysis was carried out with a PANalytical X'Pert PRO MPD diffractometer using a $\mathrm{Cu} \mathrm{K} \alpha$ radiation $(\lambda=1.54060 \AA)$ operating at $40 \mathrm{kV}$ and $40 \mathrm{~mA}$. A scanning electron microscope (SEM) (Hitachi S-4800) coupled with an electron dispersive X-ray (EDX) was used to perform elemental analysis. The $\mathrm{N}_{2}$ adsorption and desorption isotherms were measured on a Micromeritics Tristar 3000 instrument. Specific surface area determination was made using the BET isotherm. Fresh samples were vacuum dried before the adsorption measurement.

\section{RESULTS AND DISCUSSION}

\section{A. Effect of anions on phase identification and morphology of as-synthesized precursors}

The XRD patterns of the precursors are shown in Fig. 1(A), and the XRD patterns of all as-synthesized samples can be indexed to crystalline ammonium aluminum carbonate hydroxide (AACH) with a composition of $\mathrm{NH}_{4} \mathrm{Al}(\mathrm{OOH}) \mathrm{HCO}_{3}$ (JCPDS card no. 00-042-0250). As shown in Fig. 1(A), using the $\mathrm{Al}_{2}\left(\mathrm{SO}_{4}\right)_{3}$ as aluminum source results in best-crystallized AACH compared to $\mathrm{Al}\left(\mathrm{NO}_{3}\right)_{3}$ and $\mathrm{AlCl}_{3}$. The effect of aluminum sources on the morphology of the precursors is also investigated (shown in Figs. 1(B), 1(C) and 1(D)). It is seen that the precursor obtained from $\mathrm{Al}_{2}\left(\mathrm{SO}_{4}\right)_{3}$ exhibites a particle morphology with some irregular rodlike particles. The length of the fiber is about $120 \mathrm{~nm}$, and the diameter is about $25 \mathrm{~nm}$. It means that crystals grew quicker along the longitudinal direction than the diametric direction. The precursor obtained from $\mathrm{Al}\left(\mathrm{NO}_{3}\right)_{3}$ also displays a particle morphology with some smaller rodlike. However, the precursor obtained from $\mathrm{AlCl}_{3}$ exhibites a multilayered nanofiber morphology. The nanofibers are not tangled, and the nanofibers have a smooth surface. The top of the nanofiber is smaller than the bottom of the nanofiber. The length of the fiber is about $370 \mathrm{~nm}$. The above results indicate anions play an important role in controlling the crystallinity and morphology of AACH.

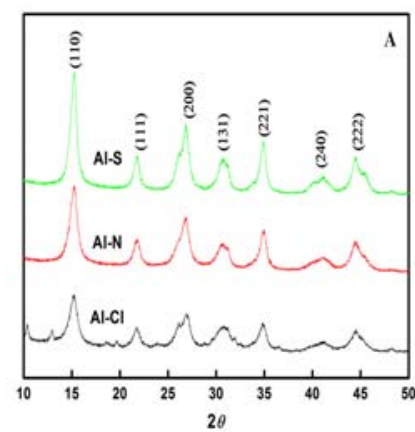

(A)

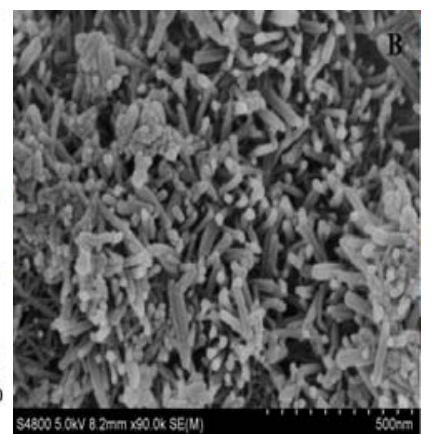

(B)

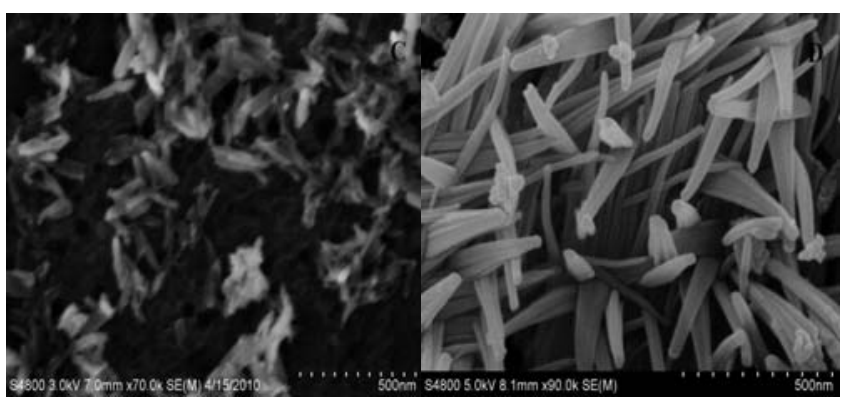

(C)

(D)

Figure 1. The SEM photographs of the samples (B) Al-S, (C) Al-N and (D) $\mathrm{Al}-\mathrm{Cl}$.

\section{B. Effect of anions on thermal decomposition behaviors of as- synthesized precursors}

The decomposition of AACH phase can be described by the following reaction:

$2 \mathrm{NH}_{4} \mathrm{AlO}(\mathrm{OH}) \mathrm{HCO}_{3} \rightarrow \mathrm{Al}_{2} \mathrm{O}_{3} \cdot \mathrm{nH}_{2} \mathrm{O}+2 \mathrm{CO}_{2}+2 \mathrm{NH}_{3}+(3-\mathrm{n}) \mathrm{H}_{2} \mathrm{O}$

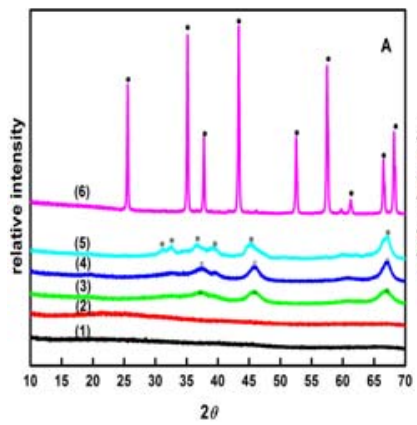

(A)

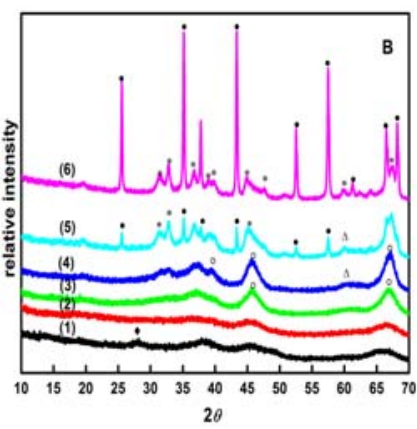

(B)
Figure 2. (A)X-ray diffraction patterns of $\mathrm{AACH}$ obtained from $\mathrm{Al}_{2}\left(\mathrm{SO}_{4}\right)_{3}$ after heat treatment at different temperatures: (1) $300^{\circ} \mathrm{C}$; (2) $400^{\circ} \mathrm{C}$; (3) $800^{\circ} \mathrm{C}$ (4) $900^{\circ} \mathrm{C}$; (5) $1000^{\circ} \mathrm{C}$; (6) $1100^{\circ} \mathrm{C}$. (B) X-ray diffraction patterns of AACH obtained from $\mathrm{Al}\left(\mathrm{NO}_{3}\right)_{3}$ after heat treatment at different temperatures: (1) $300^{\circ} \mathrm{C}$; (2) $700^{\circ} \mathrm{C}$; (3) $800^{\circ} \mathrm{C}$; (4) $900^{\circ} \mathrm{C}$; (5) $1000^{\circ} \mathrm{C}$; (6) $1100^{\circ} \mathrm{C}$. ((*) $\theta$ -

$\mathrm{Al}_{2} \mathrm{O}_{3} ;(\cdot) \alpha-\mathrm{Al}_{2} \mathrm{O}_{3} ;(\diamond)$ pseudo-boehmite; (。 ) $\left.\gamma-\mathrm{Al}_{2} \mathrm{O}_{3} ;(\Delta) \delta-\mathrm{Al}_{2} \mathrm{O}_{3}\right)$

Fig. 2(A) shows the X-ray diffraction patterns obtained from the calcination of $\mathrm{AACH}$ obtained from $\mathrm{Al}_{2}\left(\mathrm{SO}_{4}\right)_{3}$ in the temperature range $300-1100^{\circ} \mathrm{C}$. During the process of calcination, the following series of phase transformations take place to form $\alpha-\mathrm{Al}_{2} \mathrm{O}_{3}{ }^{[11.92]}: \mathrm{NH}_{4} \mathrm{AlO}(\mathrm{OH}) \mathrm{HCO}_{3} \rightarrow$ amorphous $\mathrm{Al}_{2} \mathrm{O}_{3} \rightarrow \gamma-\mathrm{Al}_{2} \mathrm{O}_{3} \rightarrow \theta-\mathrm{Al}_{2} \mathrm{O}_{3} \rightarrow \alpha-\mathrm{Al}_{2} \mathrm{O}_{3}$. At $300-700^{\circ} \mathrm{C}$, amorphous $\mathrm{Al}_{2} \mathrm{O}_{3}$ appears. At $800^{\circ} \mathrm{C}$, the $\gamma-\mathrm{Al}_{2} \mathrm{O}_{3}$ starts to emerge, and it becomes more apparent at $800-900^{\circ} \mathrm{C}$. At $1000^{\circ} \mathrm{C}$, the $\theta-\mathrm{Al}_{2} \mathrm{O}_{3}$ starts to emerge. With a higher calcination temperature at $1100^{\circ} \mathrm{C}$, the $\alpha-\mathrm{Al}_{2} \mathrm{O}_{3}$ appears. $\mathrm{AACH}$ obtained from $\mathrm{Al}_{2}\left(\mathrm{SO}_{4}\right)_{3}$ and $\mathrm{AlCl}_{3}$ have the similar phase transformations. However, phase transformations of $\mathrm{AACH}$ obtained from $\mathrm{Al}\left(\mathrm{NO}_{3}\right)_{3}$ are different. Fig. 2(B) shows the Xray diffraction patterns obtained from calcination of $\mathrm{AACH}$ obtained from $\mathrm{Al}\left(\mathrm{NO}_{3}\right)_{3}$ in the temperature range $300-1100^{\circ} \mathrm{C}$. During thermal treatment, the following series of phase transformations take place to form $\alpha-\mathrm{Al}_{2} \mathrm{O}_{3}$ [11,12]: $\mathrm{NH}_{4} \mathrm{AlO}(\mathrm{OH}) \mathrm{HCO}_{3} \rightarrow \mathrm{Al}_{2} \mathrm{O}_{3} \cdot \mathrm{nH}_{2} \mathrm{O} \rightarrow \gamma-\mathrm{Al}_{2} \mathrm{O}_{3} \rightarrow \delta-\mathrm{Al}_{2} \mathrm{O}_{3} \rightarrow$ $\theta-\mathrm{Al}_{2} \mathrm{O}_{3} \rightarrow \alpha-\mathrm{Al}_{2} \mathrm{O}_{3}$. At $300^{\circ} \mathrm{C}$, both pseudo-boehmite and $\gamma$ - 
$\mathrm{Al}_{2} \mathrm{O}_{3}$ patterns appear. At $400^{\circ} \mathrm{C}$, the $\gamma-\mathrm{Al}_{2} \mathrm{O}_{3}$ starts to emerge, and it becomes more apparent at $500-800^{\circ} \mathrm{C}$. At $1000^{\circ} \mathrm{C}, \gamma-$ $\mathrm{Al}_{2} \mathrm{O}_{3}$ disappears, and $\delta-\mathrm{Al}_{2} \mathrm{O}_{3}, \theta-\mathrm{Al}_{2} \mathrm{O}_{3}, \alpha-\mathrm{Al}_{2} \mathrm{O}_{3}$ start to emerge. With a higher calcination temperature at $1100^{\circ} \mathrm{C}$, the $\theta-\mathrm{Al}_{2} \mathrm{O}_{3}$ and $\alpha-\mathrm{Al}_{2} \mathrm{O}_{3}$ appear. It can be proved that the phase transformations of AACH are closely related with anions of aluminum sources.

\section{Effect of anions on textural properties and morphology of alumina}

TABLE II. TeXtural Properties of SOME RePresentative SAMPleS CALCINED AT $500^{\circ} \mathrm{C}$ FOR $4 \mathrm{H}$.

\begin{tabular}{|c|c|c|c|}
\hline \multirow[b]{2}{*}{ Sample } & \multicolumn{3}{|c|}{ Textural Properties } \\
\hline & $\begin{array}{l}\text { BET specific surface } \\
\quad \text { area }\left(m^{2} \cdot g^{-1}\right)\end{array}$ & $\begin{array}{c}\text { Pore } \\
\text { volume }\left(m L \cdot g^{-1}\right)\end{array}$ & $\begin{array}{c}\text { Average } \\
\text { Pore } \\
\text { Size }(\mathrm{nm})\end{array}$ \\
\hline Al-S & 610.6 & 1.1 & 7.56 \\
\hline Al-N & 303.6 & 1.0 & 10.62 \\
\hline $\mathrm{Al}-\mathrm{Cl}$ & 420.2 & 1.2 & 8.18 \\
\hline
\end{tabular}
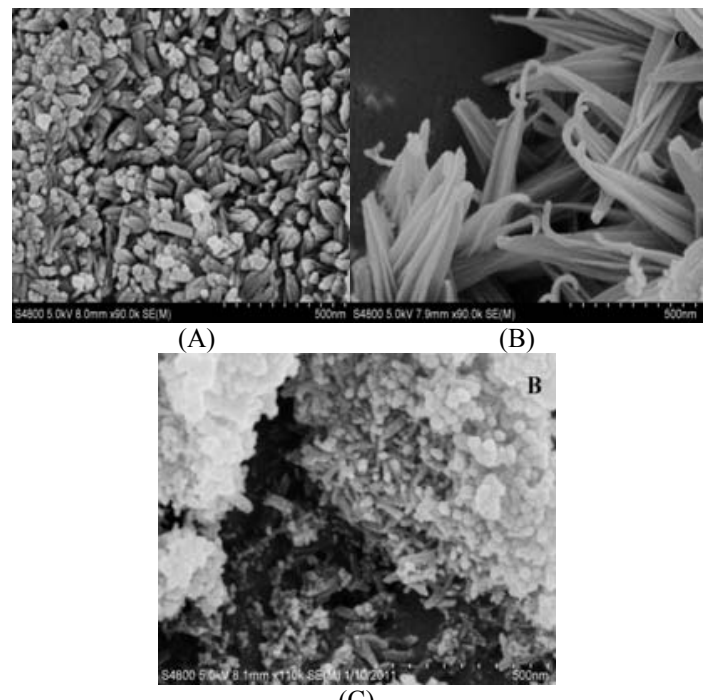

(C)

Figure 3. The SEM photographs of the samples (A), (B) and (C) obtained from $\mathrm{Al}_{2}\left(\mathrm{SO}_{4}\right)_{3}, \mathrm{Al}\left(\mathrm{NO}_{3}\right)_{3}$ and $\mathrm{AlCl}_{3}$ calcined at $500^{\circ} \mathrm{C}$ for $4 \mathrm{~h}$

Table 2 lists textural properties measured for samples obtained from $\mathrm{Al}_{2}\left(\mathrm{SO}_{4}\right)_{3}, \mathrm{Al}\left(\mathrm{NO}_{3}\right)_{3}$ and $\mathrm{AlCl}_{3}$ calcined at $500^{\circ} \mathrm{C}$ for $4 \mathrm{~h}$. The pore volume should be attributed to the intercrystallite voids of the randomly stacked alumina nanostructure. The surface area of the sample obtained from $\mathrm{Al}_{2}\left(\mathrm{SO}_{4}\right)_{3}$ has the maximum value. Accordingly, the average pore size of the sample obtained from $\mathrm{Al}_{2}\left(\mathrm{SO}_{4}\right)_{3}$ has the minimum value of $7.56 \mathrm{~nm}$. The effect of anions on the morphology of alumina is also investigated. The Fig. 3 shows the SEM photographs of the sample obtained from $\mathrm{Al}_{2}\left(\mathrm{SO}_{4}\right)_{3}$, $\mathrm{Al}\left(\mathrm{NO}_{3}\right)_{3}$ and $\mathrm{AlCl}_{3}$ calcined at $500^{\circ} \mathrm{C}$ for $4 \mathrm{~h}$. It is seen that the sample obtained from $\mathrm{Al}_{2}\left(\mathrm{SO}_{4}\right)_{3}$ exhibits a particle morphology with the aggregation of nanorod particles. The length of the aggregation of some nanorod particles is about $120 \mathrm{~nm}$, and the diameter is about $40 \mathrm{~nm}$. The sample obtained from $\mathrm{Al}\left(\mathrm{NO}_{3}\right)_{3}$ shows that some rodlike particles keep partially as before, and another particles break into fragments during the calcination process compared to the precursor (see Fig. 1(C)). And the sample obtained from $\mathrm{AlCl}_{3}$ presents curving nanowires on the top of the nanofibers during the calcination process, which reveals that the nanofiber is consisted with multilayer structure which may be formed by assembling of nanowires ${ }^{[13]}$. The equations are an exception to the prescribed specifications of this template. You will need to determine whether or not your equation should be typed using either the Times New Roman or the Symbol font (please no other font). To create multileveled equations, it may be necessary to treat the equation as a graphic and insert it into the text after your paper is styled.

\section{REFERENCES}

[1] H. Cölfen, S. Mann, "Higher-Order organization by mesoscale selfassembly and transformation of hybrid nanostructures," Angew. Chem. Int. Ed., vol. 42, pp. 2350-2365, 2003.

[2] Y.N. Xia, P.D. Yang, Y.G. Sun, Y.Y.Wu, B. Mayers, B. Gates, Y.D. Yin, F. Kim, H. Q.Yan, "One-dimensional nanostructures: synthesis, charaterization, and applications, " Adv.Mater., vol. 15, pp. 353-389, 2003.

[3] X. Bokhimi, J.A. Toledo,M.L. Guzman, B.Mar-Mar, F. Hernandez, J. Navarrete, "Dependence of boehmite thermal evolution on its atom bond lengths and crystallite size," J. Solid State Chem., vol. 161, pp. 319-326, 2001.

[4] M.L. Guzmánn-Castillo, X. Bokhimi, A. Toledo-Antonio, J. SalmonesBlásquez, F. Hernández-Beltrán, "Effect of boehmite crystallite size and steaming on alumina properties," J. Phys. Chem. B., vol. 105, pp. 20992106, 2001.

[5] G.C. Li, Y.Q. Liu, L. L. Guan, X. F. Hu, C.G. Liu. "Meso/macroporous $\gamma-\mathrm{Al}_{2} \mathrm{O}_{3}$ fabricated by thermal decomposition of nanorods ammonium aluminium carbonate hydroxide," Material Research Bulletin., vol. 47, pp. 1073-1079, 2012.

[6] X.F. Hu, Y.Q. Liu, Z. Tang, G.C. Li, R.Y. Zhao, C.G. Liu, "Fabrication of high-surface-area $\gamma$-alumina by thermal decomposition of AACH precursor using low-temperature solid-state reaction," Material Research Bulletin., 2012.

[7] G.C. Li, Y.Q. Liu, D. Liu, L. H. Liu, C.G. Liu. "Synthesis of flower-like Boehmite (AlOOH) via a simple solvothermal process without surfactant," Material Research Bulletin., vol. 45, pp. 1487-1491, 2010.

[8] K. Hellgardt, D. Chadwick, "Effect of pH of Precipitation on the Preparation of High Surface Area Aluminas from Nitrate Solutions," Ind. Eng. Chem. Res., vol. 37, pp. 405-411, 1998.

[9] L. Ji, J. Lin, K.L. Tan, H.C. Zeng, "Synthesis of High-Surface-Area Alumina Using Aluminum Tri-sec-butoxide-2,4-Pentanedione-2Propanol-Nitric Acid Precursors," Chem. Mater., vol. 12, pp. 931-939, 2000.

[10] S. Ramanathan, S.K. Roy, R. Bhat, D.D. Upadhyaya, A.R. Biswas. "Alumina powders from aluminium nitrate-urea and aluminium sulphate-urea reactions-the role of the precursor anion and process conditions on characteristics," Cerumics Inrernutwnul., vol. 23, pp. 4553, 1997.

[11] Xudong Sun, Jiguang Li, Fang Zhang, Xiaomei Qin, Zhimeng Xiu, and Hongqiang $\mathrm{Ru}$. "Synthesis of nanocrystalline $\gamma-\mathrm{Al}_{2} \mathrm{O}_{3}$ powders from nanometric ammonium aluminum carbonate hydroxide," J. Am. Ceram. Soc., vol. 86, pp. 1321-1325, 2003.

[12] K. Morinaga, T. Torikai, K. Nakagawa, S. Fujino. "Fabrication of fne $\alpha-$ alumina powders by thermal decomposition of ammonium aluminum aarbonate hydroxide (AACH)," Acta. Mater., vol. 48, pp. 4735-4941, 2002.

[13] Zhenfeng Zhu, Hui Liu, Hongjun Sun, Dong Yang. "PEG-directed hydrothermal synthesis of multilayered alumina microfibers with mesoporous structures," Microporous Mesoporous Mater., vol. 123, pp. 39-44, 2009. 